\title{
Perceived barriers to physical activity during the 2 nd lockdown in a northeastern state of Brazil
}

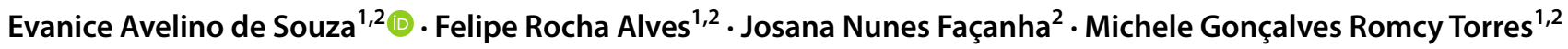

Received: 6 June 2021 / Accepted: 7 August 2021 / Published online: 2 September 2021

(c) The Author(s), under exclusive licence to Springer-Verlag Italia S.r.l., part of Springer Nature 2021

\begin{abstract}
Background The practice of physical activity has been recommended during the pandemic period of COVID-19 as a way of preventing the worsening of physical and mental health. After the increase in COVID-19 cases in Brazil and the new lockdown decrees, many people have reported that they are unable to engage in physical activity during the lockdown.

Aims The present study aimed to investigate the barriers to physical activity in the 2nd lockdown in the state of Ceará, Northeast Brazil.

Methods 1036 (55.6\% women) residents of the state of Ceará, Northeastern Brazil participated in the study. For data collection, a questionnaire was used including sample characterization questions, physical activity, and barriers to physical activity during the 2nd lockdown in the state of Ceará. This instrument was made available by Google Forms, between March 8th and 19th, 2021. Descriptive statistics and logistic regression were used for data analysis.

Results The three most relevant barriers were: Lack of motivation (7.3\%), lack of space at home (5.9\%) professional instructions (2.8\%). The lack of space at home barrier was associated with age $(\mathrm{OR}=2.56$; CI 95\% 1.05-6.02) and living in the capital $(\mathrm{OR}=2.53$; CI 95\% 1.26-5.33). The barriers, taking care of children (OR=3.75; CI 95\% 1.37-10.2) and increased time spent on daily activities ( $\mathrm{OR}=2.20$; CI 95\% 1.02-4.74) were associated with living in the metropolitan region.

Conclusion The lack of motivation, space at home, and professional instruction showed as being limiting factors to physical activity during the lockdown, indicating plans of action aimed at encouraging the practice of physical activity during a pandemic period.
\end{abstract}

Keywords COVID-19 $\cdot$ Physical activity $\cdot$ Barriers $\cdot$ Public health

\section{Introduction}

The World Health Organization (WHO) classified the new coronavirus, called COVID-19 as a pandemic as of March 2020 [1]. The pandemic required several measures of restriction such as social distancing, quarantine, and lockdown which included the closing of public spaces for physical activities [2-4]. In Brazil, until October 2020, the number of COVID-19 cases showed a reduction, when, still in the last months of that same year, a renewed increase of positive cases began the second wave of deaths which prompted

Evanice Avelino de Souza

profeas@gmail.com

1 Laboratory of Sleep and Biologic Rhythms, Universidade Federal do Ceará, Fortaleza, Brazil

2 Faculdade Terra Nordeste FATENE, Caucaia, Brazil some governors to decree a new lockdown with the closure of all services considered non-essential $[5,6]$.

The pandemic period along with social isolation has caused significant changes in the population's lifestyle, such as a decrease in mental health[7, 8], changes in sleep hours [9-11], eating disorders [12], an increase in sedentary behavior $[13,14]$, and a decrease in the level of physical activity [15-18].

In addition, a few studies have compared the practice of physical activity before and during the pandemic period and have identified that, although some people remain active, they are still unable to reach the recommended levels of physical activity for maintaining health $[19,20]$. Other studies showed an increase in domestic activities (daily chores) and participation in dance and yoga classes through digital platforms during social isolation [21-23], and an increase in the purchase of materials for performing physical activities 
at home, such as exercise bikes, weights and treadmills was also identified [24, 25].

Moreover, studies that aim to identify barriers to physical activity in social isolation are still scarce, given the importance of staying active to maintain physical and mental health [26]. In this context, the present study aimed to investigate the barriers to physical activity during the second wave of COVID-19 in the northeastern state of Ceará, Brazil.

\section{Methods}

This was a descriptive cross sectional study performed in the state of Ceará, located in the northeast region of Brazil. This state had a population of $8,452,381$ in 2010 and a human development index-HDI $=0.682$. This state had the second-highest number of COVID-19 cases at the beginning of 2021 and its second lockdown was decreed on March 5th. During this period, only supermarkets, pharmacies, hospitals, and gas stations continued their activities [27].

Faced with this situation, the present study was conducted between March 8th and 19th of 2021. Participants were invited through social media to answer an electronic form. Males and females over 18 years of age from any city of Ceará, were able to participate. People under 18 years of age, who did not reside in Ceará and who had duplicates answers were excluded from this study. This study was part of a larger project entitled "Motivational Factors for the Practice of Physical Activity during the 2nd Lockdown in the State of Ceará" which received ethical approval from the research ethics committee of College Terra Nordeste.

1036 individuals, from 19 to 50 years of age participated in this study (57.3\% residing in the capital) from different municipalities in the state, as shown in Fig. 1.

\section{Instruments and procedures}

All questions were entered on a form from Google Forms ${ }^{\circledR}$. This type of instrument has been recommended for its speed between planning and publishing the results, which is a relevant aspect in crisis contexts. The form was made available online through a direct link with explanatory text calls on social media (WhatsApp, Instagram, and Facebook) to people who were interested in participating in the study.

The form consisted of four sections. The first was used to obtain consent to participate in the study. The second section consisted of five objective questions related to sociodemographic aspects, including gender, age, city, education, and family income (less than minimum wage, minimum wage,

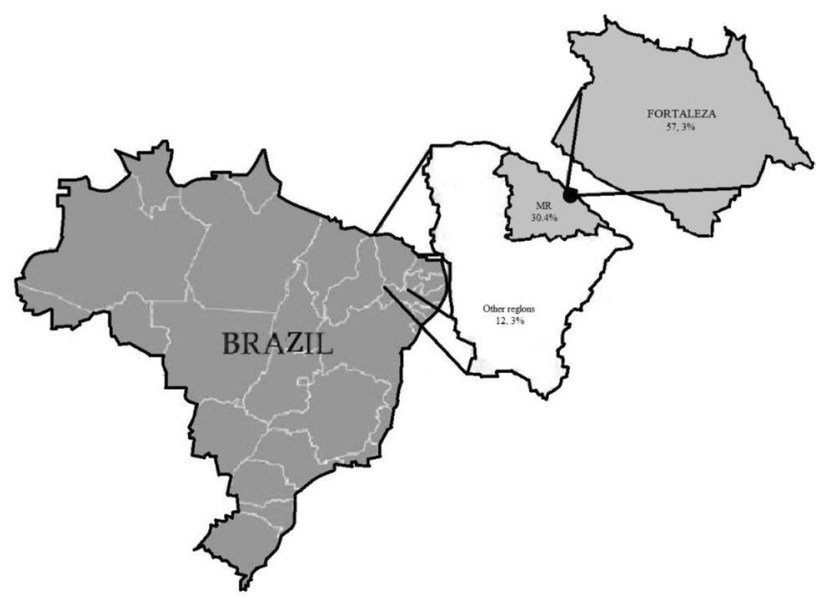

Fig. 1 Frequency distribution of participants according to capital, metropolitan region $(\mathrm{mr})$ and other municipalities of the state of Ceará

two to three times the minimum wage, four to six times the minimum wage, more than six times the minimum wage).

The third section consisted of two questions: "Did you practice physical activity before the 2 nd lockdown?" and "Did you practice physical activity during the 2nd lockdown?" If the participants reported that they were not active, they would move to the fourth section and answer the following question: "Why are you not participating in physical activity?" with multiple choice answers, such as: Lack of motivation, lack of physical space at home, taking care of the children, increased time spent on daily activities (home office and daily chores), lack of professional instruction and "other". In this last option, respondents could describe what the barrier was. To elaborate the this fourth section, we used the instrument used by MorenoLlamas, Garc1'a-Mayor; Cruz-Sa'nchez to identify the barriers to physical activity in the European population [28]. and the "other" section was based on other national research [29].

\section{Statistical analysis}

Initially, the Kolmogorov-Smirnov test was applied to assess the data normality and descriptive statistics for presenting the results. The odds ratio with a $95 \%$ confidence interval was obtained through binary logistic regression and used to analyze the chance of presenting the barriers during the period of lockdown associated with gender, age, place of residence (capital, metropolitan region, or countryside), education and financial income. The criterion adopted for the inclusion of the variables was the association with the dependent variable $(p<0.20)$. For all 
Table 1 Demographics characteristics of the participants

\begin{tabular}{lc}
\hline Variables & $\mathrm{n}(\%)$ \\
\hline Gender & \\
Male & $464(44.8)$ \\
Female & $572(55.6)$ \\
Age (years) & \\
19-25 & $285(27.5)$ \\
$26-32$ & $299(28.9)$ \\
$33-39$ & $224(21.6)$ \\
$>40$ years of age & $228(22.0)$ \\
Educational level & \\
Incomplete basic education & $26(2.5)$ \\
Complete basic education & $203(19.6)$ \\
Incomplete higher education & $265(25.6)$ \\
Complete higher education & $542(52.3)$ \\
Income & \\
Less than minimum wage & $35(3.4)$ \\
Minimum wage & $134(12.9)$ \\
2 to 4 times the minimum wage & $472(45.6)$ \\
4 to 6 times the minimum wage & $232(22.4)$ \\
More than 6 times the minimum wage & $163(15.7)$ \\
\hline
\end{tabular}

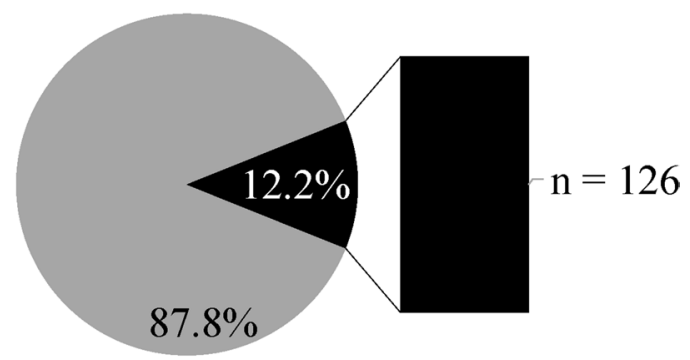

Yes $\mathbf{n o}$

Fig. 2 Frequency of participants and non-participants in PA during the 2 nd lockdown of the state of Ceará analyses, a 5\% significance level was adopted using the SPSS 21.0 software.

\section{Results}

The present study was comprised of 1036 participants (55.6\% girls), being mostly (28.9\%) 26-32 years of age. Overall, $52.3 \%$ of the participants had completed higher education, and $45.6 \%$ made from 1 to 4 times the minimum wage as shown in Table 1.

Concerning the practice of physical activity during the 2nd lockdown, it was verified that the majority of participants reported practicing some kind of physical activity (Fig. 2).

Lack of motivation 76 (7.3\%) and lack of physical space in the residence 61 (5.9\%) were the main barriers to physical activity during the 2nd lockdown as shown in Fig. 3.

The odds ratio analysis showed significant associations between being $<18$ years old (3.87), 19-25-years old $(\mathrm{CI}=1.05)$, and living in the capital $(\mathrm{CI}=2.56)$ with the lack of space at home. The barriers, taking care of children $(\mathrm{OR}=3.75)$ and increased time spent on daily activities $(\mathrm{OR}=2.20)$ were associated with living in the metropolitan region, as shown in Fig. 4.

\section{Discussion}

The present study aimed at investigating the main barriers to physical activity during the 2nd lockdown, in a northeastern state of Brazil. The results indicated that the lack of motivation was the main perceived barrier to participating in any physical activity, followed by the lack of physical space and adequate professional instruction. It is important to report that, until now, most studies have aimed at investigating the levels of physical activity, most

Fig. 3 Perceived barriers to participation in physical activity during the 2nd lockdown of the State of Ceará, Northeastern Brazil. $L M$ lack of motivation, ITSDA increased time spent on daily activities, $L P S R$ lack of physical space in the residence, TCC taking care of children, $A P I$ adequate professional instruction

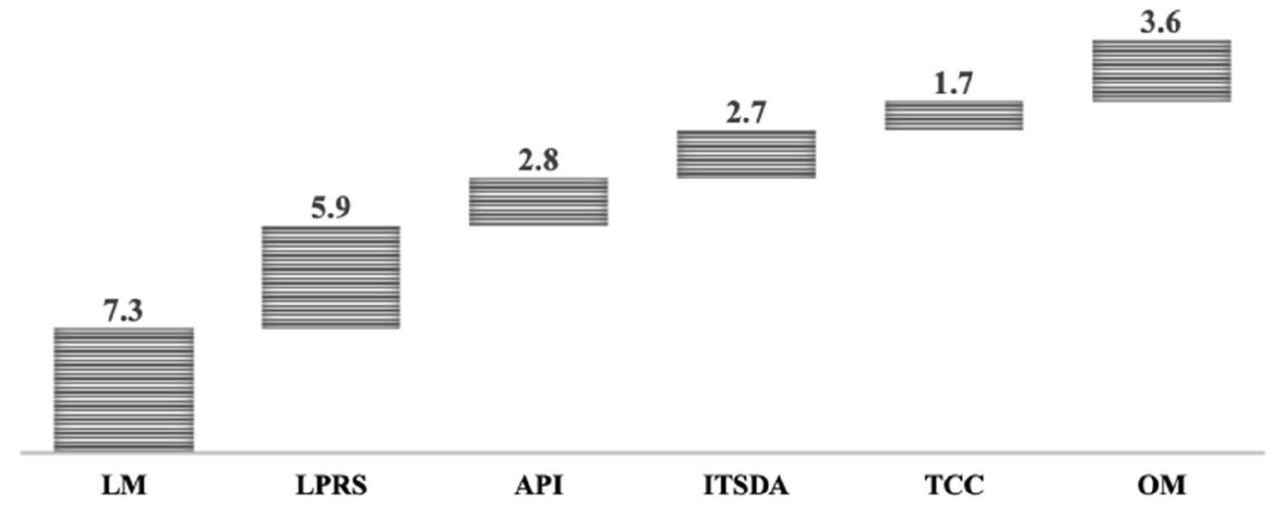


Fig. 4 Factors associated with barriers to physical activity: a increased working hours, b lack of space in the residence and $\mathbf{c}$ taking care of children a Lack of physical space in the residence

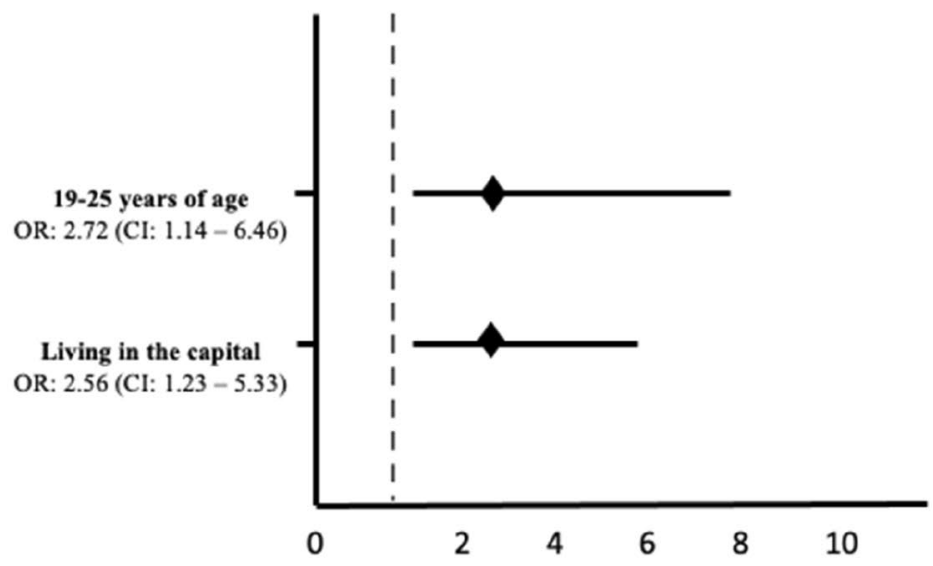

b increased time spent on daily activities

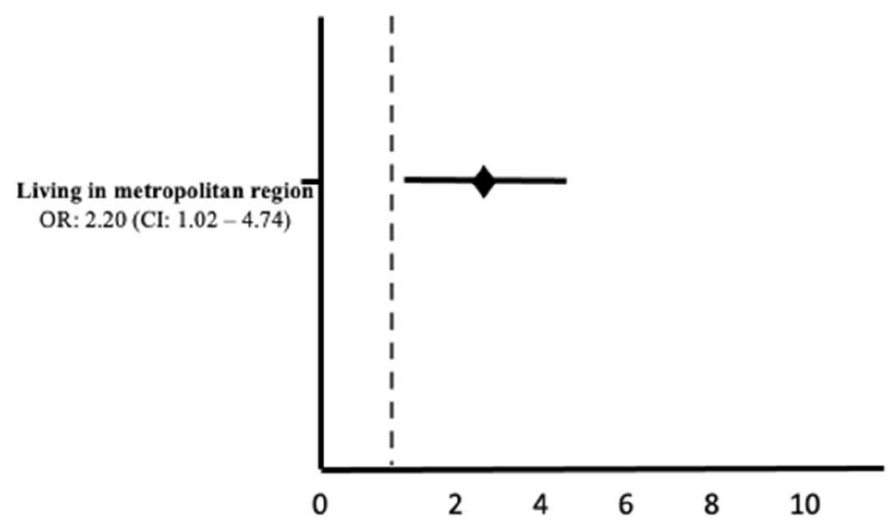

c Talking care of children

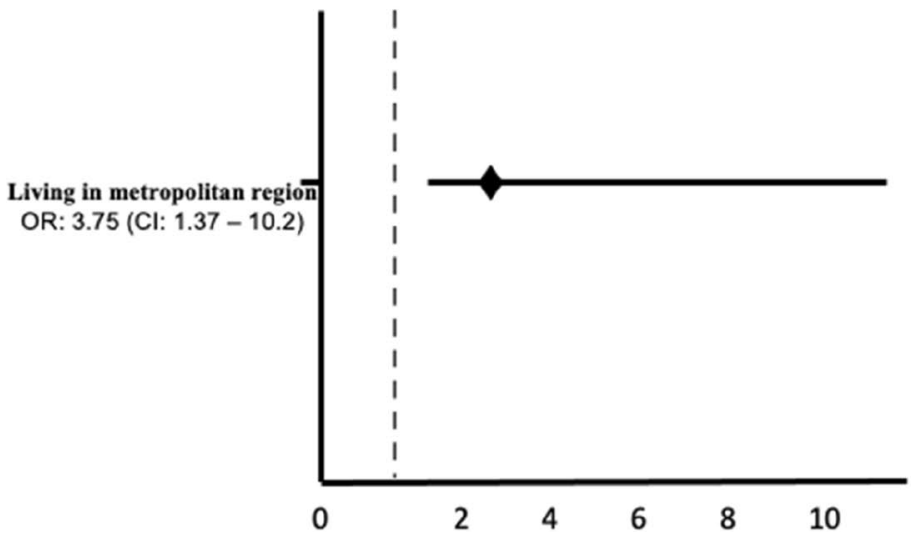


practiced activities, or factors associated with physical activity practice during the pandemic and/or the beginning of the lockdown [16, 21, 30-35].

The lack of motivation was the main barrier reported in the present study which is similar to the results demonstrated in previous studies [30,36-42] that reported the negative impact of social distancing on mental health. In times of social isolation, many people are discouraged due to the number of hours spent at home, increase in household chores [43], and changes in the work routine, which can cause discouragement to practice physical activity at home. Feeling discouraged can be considered natural in this chaotic and abnormal scenario of the COVID-19 pandemic which we are currently in, where the fear of the coronavirus, uncertainties about the future, and news about hundreds of deaths per day are combined [41]. In the state of Ceará, 552,009 positive cases and 14,407 deaths have been reported during the second wave of COVID-19, with this northeastern state of Brazil having the most cases until March 2021 [44].

A study carried out in the United Kingdom with 1521 adults aimed at examining the impact of the lockdown period on motivational factors for physical activity, identified that if the adults were motivated enough it would have been possible for them to have maintained or increased their levels of physical activity during lockdown [45]. Therefore, it is relevant that in addition to promoting physical activity in the pursuit of maintaining active behavior, activities that provide greater mental well-being, such as games and dancing, are also encouraged [46-49].

Another study of 2,004 participants (adults) from different countries aimed at analyzing the impact of social isolation on physical activity and mental well-being in Pokémon GO or Harry Potter players: On Wizards Unite, it was found that $77.2 \%$ of participants reported as beneficial the use of electronic games for their mental health, mainly as a way of maintaining a social connection. Therefore, the authors of the study indicated that it would be interesting to develop interactive software during the period of social isolation to maintain holistic well-being [50].

In the present study, the second greatest barrier perceived for participating in physical activity was the lack of physical space. This barrier was associated with age and living in the capital. Although in our study, the lack of physical space in the residence presents itself as one of the main obstacles to participation in practicing physical activity, a pioneer study carried out in the city of Bagé in southern Brazil, with 377 adults, which aimed to describe the practice of physical activity during the COVID-19 pandemic, pointed out a prevalence of individuals who practiced physical activity at home [51]. A survey carried out in Brazil with 16,440 individuals aimed at describing the aspects related to people's behavior and how they were being affected during the social isolation imposed by the COVID-19, identified that $37 \%$ of the people claimed that their residence did not have any open area (terrace, yard, green area) and $18 \%$ considered their home's adequate space to be regular, bad or terrible [52]. Given the specifics of coping with the pandemic, there are still few studies that have been conducted with the Brazilian population with the objective similar to that of the present study. However, the findings of the studies previously mentioned, have shown a great economic disparity in Brazil, since the majority of homes, mainly the ones located in large cities, such as the one in this study, do not have large physical spaces, as the large part of the population live in small houses with a large family. This makes it difficult to perform tasks imposed by the pandemic, including practicing physical activity at home [53].

In large Brazilian cities, the tendency is to reduce environments and shared spaces, but, after the changes caused by COVID-19, new approaches are required. Since they are spending more time indoors, people begin to miss a more structured space, with more spacious and airy environments, which can apply the adaptations that the pandemic has required, such as, for example, spaces to study, work and practice physical activity [54].

In addition to the lack of physical space in the residence, the lack of professional instruction was also reported by the participants in the present study as one of the main barriers to physical activity. In Brazil, walking is the most practiced activity, mainly because it has no financial cost and is done in public spaces. Therefore, due to the pandemic, many people were unable to perform this activity, given the decrees of social isolation [55]. While there is a lot of information and tips on physical activity practices on virtual platforms [56], there is still little guidance $[26,57,58]$ for people to practice physical activity without using any equipment at home, in parallel to stimulating the reduction of time in sedentary behavior activities to help people remain active, regardless of the size of their residence [59].

A study carried out with 592 people from different regions of Brazil, investigated the relationship between physical activities and people's well-being after a week of social isolation and identified that people felt bad when doing the exercises that were being prescribed by digital platforms. The authors of that study suggest that this relationship could be associated with the lack of individualization in the exercise prescription. Therefore, it is important that, given the current pandemic scenario that the world is experiencing, professionals may use digital platforms for individualized services [60].

Two other barriers to participation in physical activity found in the present study were: doing daily activities at home and taking care of children. The two barriers mentioned above have been the most investigated factors during the pandemic period [61-67] due to the impact on the 
physical and mental health of many individuals. The sudden adoption of the home office during the period of social isolation forced professionals and their families to adapt to the new reality: intensification of domestic activities due to the absence of previously hired services; schools and universities using digital platforms to deliver content; the meetings with friends/family started being done online or at distance [68], that is, the practice of physical activity would be more of a task to be done, due to the increase of so many other changes that were happening and demanding greater dedication among people.

The present study had some limitations: first, for having used a virtual instrument, which was limited to presenting information from individuals who had access to the internet. However, this type of instrument has been the most used during the pandemic period. The second limitation was how the data were revealed and discussed. Despite having been collected in the entire state of Ceará and different segments of the population, this process presented itself as the main limitation to the convenience sample. The method by which the data collection was carried out can lead to a sample with better socioeconomic conditions, which may explain the majority of the sample being composed of individuals with higher education. In addition, in this method of data collection, individuals who show some appreciation for physical activity may be more willing to respond to the forms. However, this was the safest and most comprehensive way to research during this lockdown period.

Considering the little information found in the literature about barriers to physical activity during times of pandemic, these findings are relevant, as they provide information that can serve as subsidies for interventions. Thus, the study has practical implications for thinking about ways to encourage the practice of physical activity during periods of social distancing.

\section{Conclusion}

The study showed that during the 2 nd lockdown of the state of Ceará most people continued doing physical activity. However, the lack of motivation and physical space were the main barriers to remaining active. Thus, it is suggested that the recommendations for the practice of physical activity may consider the barriers identified in this and future studies since after a year of pandemic there is still no tendency for a significant reduction in new cases in Brazil.

\section{Declarations}

Conflict of interest The authors declare that they have no conflict of interest.
Ethical approval The study was approved by the College Terra Nordeste Human Research Ethics Committee (Ethics Register Number: 4.677.429).

Informed consent Informed consent was obtained from all individual participants.

\section{References}

1. Werneck GL, Carvalho MS (2020) A pandemia de COVID-19 no Brasil: crônica de uma crise sanitária anunciada

2. OMS. ONU News [Internet]. Covid-19: OMS divulga guia com cuidados para saúde mental durante pandemia. 2020. p. 1-10. [Citado em 2020 de jul 9]. Disponível em: https://news.un.org/ pt/story/2020/03/1707792. Acesso em: 05 abr. 2021

3. Neca BR, Rechia S (2020) Ficar em Casa ou Ocupar os Espaços de Lazer ao Ar Livre?: Reflexões e Possibilidades para uma Apropriação Segura dos Diferentes Espaços Públicos de Lazer em Tempos de Pandemia. LICERE-Revista do Programa de Pós-graduação Interdisciplinar em Estudos do Lazer 23(4):471-509

4. Wang $C$ et al (2020) Immediate psychological responses and associated factors during the initial stage of the 2019 coronavirus disease (COVID-19) epidemic among the general population in China. Int J Environ Res Public Health 17(5):1729

5. Santos VS dos (2021) "Segunda onda de covid-19 no Brasil"; Brasil Escola. Disponível em: https://brasilescola.uol.com.br/doenc as/segunda-onda-de-covid-19-no-brasil.htm. Acesso em 23 de abril de 2021

6. Lopes TS (2021) Impacto do lockdown pela pandemia por covid19 em pacientes com disfunção temporomandibular-um estudo caso-controle

7. Heitzman $\mathbf{J}$ (2020) Impact of COVID-19 pandemic on mental health. Psychiatr Pol 54(2):187-198. https://doi.org/10.12740/ $\mathrm{PP} / 120373$

8. Vindegaard N, Benros ME (2020) COVID-19 pandemic and mental health consequences: systematic review of the current evidence. Brain Behav Immun 89:531-542. https://doi.org/10. 1016/j.bbi.2020.05.048

9. Souza EA (2020) Long Sleep Duration in University Students during the Covid-19 Quarantine in Brazil. Scientific Journal of Research in Dentistry. Department of Clinical Medicine, Federal University of Ceara, Fortaleza, Brazil. Set de 2020

10. Alnofaiey $\mathrm{YH}$, Alshehri HA, Alosaimi MM, Alswat SH, Alswat RH, Alhulayfi RM, Alghamdi MA, Alsubaie RM (2020) Sleep disturbances among physicians during COVID-19 pandemic. BMC Res Notes 13(1):493. https://doi.org/10.1186/ s13104-020-05341-6

11. Trakada A, Nikolaidis PT, Andrade MDS, Puccinelli PJ, Economou NT, Steiropoulos P, Knechtle B, Trakada G (2020) Sleep During "Lockdown" in the COVID-19 Pandemic. Int J Environ Res Public Health 17(23):9094. https://doi.org/10.3390/ijerp h17239094

12. Castellini G, Cassioli E, Rossi E, Innocenti M, Gironi V, Sanfilippo G, Felciai F, Monteleone AM, Ricca V (2020) The impact of COVID-19 epidemic on eating disorders: a longitudinal observation of pre versus post psychopathological features in a sample of patients with eating disorders and a group of healthy controls. Int J Eat Disord 53(11):1855-1862. https://doi.org/10.1002/eat.23368

13. Romero-Blanco C, Rodríguez-Almagro J, Onieva-Zafra MD, Parra-Fernández ML, Prado-Laguna MDC, Hernández-Martínez A (2020) Physical activity and sedentary lifestyle in university students: changes during confinement due to the COVID-19 pandemic. Int J Environ Res Public Health 17(18):6567. https://doi. 
org/10.3390/ijerph17186567.PMID:32916972;PMCID:PMC75 58021

14. Zheng C, Huang WY, Sheridan S, Sit CH, Chen XK, Wong SH (2020) COVID-19 pandemic brings a sedentary lifestyle in young adults: a cross-sectional and longitudinal study. Int J Environ Res Public Health 17(17):6035. https://doi.org/10.3390/ijerph1717 6035

15. Malta DC, Szwarcwald CL, Barros MBDA, Gomes CS, Machado ÍE, Souza Júnior PRBD et al (2020) A pandemia da COVID19 e as mudanças no estilo de vida dos brasileiros adultos: um estudo transversal 2020. Epidemiologia e Serviços de Saúde 29:e2020407

16. Lesser IA, Nienhuis CP (2020) The impact of COVID-19 on physical activity behavior and well-being of Canadians. Int J Environ Res Public Health 17(11):3899

17. Ammar A, Brach M, Trabelsi K, Chtourou H, Boukhris O, Masmoudi L et al (2020) Efeitos do confinamento domiciliar COVID19 no comportamento alimentar e atividade física: resultados da pesquisa online internacional ECLB-COVID19. Nutrients 12(6): 1583

18. Amini H, Isanejad A, Chamani N, Movahedi-Fard F, Salimi F, Moezi M, Habibi S (2020) Physical activity during COVID19 pandemic in the Iranian population: a brief report. Heliyon 6(11):e05411

19. Cheval B, Sivaramakrishnan H, Maltagliati S, Fessler L, Forestier C, Sarrazin P, Orsholists D, Chalabaev A, Sander D, Ntoumanis $\mathrm{N}$, et al. (2020) Relationships between changes in self-reported physical activity and sedentary behaviours and health during the coronavirus (COVID-19) pandemic in France and Switzerland. J Sports Sci 1-6

20. Pérez-Rodrigo C, Gianzo Citores M, Hervás Bárbara G, RuizLitago F, Casis Sáenz L, Arija V et al (2021) Patterns of change in dietary habits and physical activity during lockdown in Spain due to the COVID-19 pandemic. Nutrients 13(2):300

21. Rodrigues $\mathbf{P}$ et al (2020) Fatores associados à prática de atividades físicas durante a pandemia da COVID-19 no estado do Rio de Janeiro, Brasil. Revista Brasileira de Atividade Física Saúde 25:1-9

22. Pesquisa revela quais exercícios mais praticados durante quarentena. Lance, 2020. Disponível em: https://www.lance.com.br/ fora-de-campo/pesquisa-revela-quais-exercicios-mais-prati cados-durante-quarentena.html. Acesso em 15, abr 2021

23. Mattos SM et al (2020) Recomendações de atividade física e exercício físico durante a pandemia Covid-19: revisão de escopo sobre publicações no Brasil. Revista Brasileira de Atividade Física Saúde 25:1-12

24. Wood L (2021) Vendas de equipamentos de ginástica aumentam $170 \%$ durante o bloqueio do Coronavirus-ResearchAndMarkets.com. Disponível em: https://www.businesswire.com/news/ home/20200507005477/en/Fitness-Equipment-Sales-Grow-by170-During-Coronavirus-Lockdown---ResearchAndMarkets. com. Acesso em: 15 abr 2021

25. Larghi $\mathrm{N}$ (2021) Com quarentena, venda de itens para exercícios em casa cresce até 10 vezes. Disponível em: https://valorinves te.globo.com/mercados/renda-variavel/empresas/noticia/2020/ 04/06/com-quarentena-venda-de-itens-para-exercicios-em-casacresce-ate-10-vezes.ghtml. Acesso em 16 abr 2021

26. Pitanga FJG, Beck CC, Pitanga CPS (2020) Atividade física e redução do comportamento sedentário durante a pandemia do Coronavírus. Arq Bras Cardiol 114(6):1058-1060

27. IBGE_-Instituto Brasileiro De Geografia E Estatística. Pesquisa Nacional por Amostra de Domicílios 2009-Síntese dos indicadores. Rio de Janeiro. IBGE. p. 135-163. 2010

28. Moreno-Llamas A, García-Mayor J, De la Cruz-Sánchez E (2020) Physical activity barriers according to social stratification in Europe. Int J Public Health 65(8):1477-1484. https://doi.org/10.1007/s00038-020-01488-y

29. Rinaldi CD (2020) Pesquisa sobre o nível da prática de exercícios físicos durante a quarentena da pandemia de Covid-19 em 2020 da população da Região "Amurel” de Santa Catarina. Educação Física Licenciatura-Tubarão

30. Raiol RA (2021) Praticar exercícios físicos é fundamental para a saúde física e mental durante a Pandemia da COVID-19. Braz J Health Rev 3(2):2804-2813

31. Maugeri G et al (2020) The impact of physical activity on psychological health during Covid-19 pandemic in Italy. Heliyon 6(6): $\mathrm{e} 04315$

32. Wilke J et al (2021) A pandemic within the pandemic? Physical activity levels substantially decreased in countries affected by COVID-19. Int J Environ Res Public Health 18(5):2235

33. Füzéki E, Groneberg DA, Banzer W (2020) Physical activity during COVID-19 induced lockdown: recommendations. J Occup Med Toxicol 15(1):1-5

34. Sekulic D et al (2020) Prospective analysis of levels and correlates of physical activity during COVID-19 pandemic and imposed rules of social distancing; gender specific study among adolescents from Southern Croatia. Sustainability 12(10):4072

35. Sfendla A, Hadrya F (2020) Factors associated with psychological distress and physical activity during the COVID-19 pandemic. Health Secur 18(6):444-453

36. Puccinelli PJ et al (2021) Reduced level of physical activity during COVID-19 pandemic is associated with depression and anxiety levels: an internet-based survey. BMC Public Health 21(1):1-11

37. Faulkner J et al (2021) Physical activity, mental health and wellbeing of adults during initial COVID-19 containment strategies: a multi-country cross-sectional analysis. J Sci Med Sport 24(4):320-326

38. Hossain M et al. (2020) Epidemiologia dos problemas de saúde mental no COVID-19: uma revisão. F1000Research 9

39. Meyer $J$ et al. 2020 Changes in physical activity and sedentary behavior in response to COVID-19 and their associations with mental health in 3052 US adults. Int J Environ Res Public Health $17(18)$

40. Zhang Y et al (2020) Mental health problems during the COVID19 pandemics and the mitigation effects of exercise: a longitudinal study of college students in China. Int J Environ Res Public Health 17(10):3722

41. Tavares $\mathrm{G}$ et al (2020) Inatividade física no lazer durante a pandemia da COVID-19 em universitários de Minas Gerais. Revista Brasileira de Atividade Física Saúde 25:1-7

42. Malta DC et al. (2020) Distanciamento social, sentimento de tristeza e estilos de vida da população brasileira durante a pandemia de COVID-19

43. Oliveira AL (2020) A espacialidade aberta e relacional do lar: a arte de conciliar maternidade, trabalho doméstico e remoto na pandemia da COVID-19. Revista Tamoios 16(1)

44. Brasil, Ministério da Saúde. Covid-19 no Brasil. Disponível em: https://susanalitico.saude.gov.br/extensions/covid-19_html/covid19_html.html Acesso em 04 abr. 2021

45. Spence JC et al. (2020) Determinants of physical activity among adults in the United Kingdom during the COVID-19 pandemic: The DUK-COVID study. Br J Health Psychol

46. Ding Y et al. (2021) The effect of dance-based mind-motor activities on the quality of life in the patients recovering from COVID19: a protocol for systematic review and meta-analysis. Medicine 100(11)

47. Pires E, Prieto M, Piedade C da (2020) Confinad@s em casa: sobre dança, música e incerteza 
48. Viana RB, de Lira CAB (2020) Exergames as coping strategies for anxiety disorders during the COVID-19 quarantine period. Games Health J 9(3):147-149

49. Demers $\mathrm{M}$ et al (2020) Active video games and low-cost virtual reality: an ideal therapeutic modality for children with physical disabilities during a global pandemic. Front Neurol 11:1737

50. Ellis LA et al (2020) COVID-19 as 'Game Changer' for the physical activity and mental well-being of augmented reality game players during the pandemic: mixed methods survey study. J Med Internet Res 22(12):e25117

51. Crochemore-Silva I et al (2020) Prática de atividade física em meio à pandemia da COVID-19: estudo de base populacional em cidade do sul do Brasil. Ciência Saúde Coletiva 25:4249-4258

52. Bezerra ACV et al (2020) Fatores associados ao comportamento da população durante o isolamento social na pandemia de COVID-19. Ciência Saúde Coletiva 25:2411-2421

53. Monteiro AR, Rezende Veras AT de (2017) A questão habitacional no Brasil. Mercator (Fortaleza) 16

54. França LA (2021) Crescimento do setor imobiliário: conhecer termos do pode auxiliar na compra. Dino divulgador de Notícias. São Paulo, 9 de abril de 2021. Disponível em: https://www.terra.com. br/noticias/dino/crescimento-do-setor-imobiliario-conhecer-termos-do-pode-auxiliar-na-compra,d09d4fd1899271d1e025c84a3 2723222e4nrl6oo.html. Acesso em 27, mai 2021

55. Brasil, Ministério da Saúde. Secretaria de Vigilância em Saúde. Estimativa sobre frequência e distribuição sócio-demográfica de fatores de riscos proteção para doenças crônicas nas capitais dos 26 estados brasileiros e no Distrito Federal em 2017

56. Almeida TP de (2019) A influência das redes sociais online na prática esportiva do adolescente. 2019. Trabalho de Conclusão de Curso. Universidade Tecnológica Federal do Paraná

57. Brasil. Ministério da Cidadania. Secretaria Especial de Esportes. Orientações sobre a prática de atividade física durante o período de pandemia. Brasília-DF, 2020

58. Sanseverino M, Silva A et al. (2020). Como "achatar a curva" em casa: cartilha sobre a prática de atividade física durante a pandemia da COVID-19
59. Carvalho VO, Gois CO (2020) Pandemia de COVID-19 e atividade física domiciliar. J Allergy Clin Immunol Practice $8(8): 2833-2834$

60. Dantas DN et al (2021) Educação em saúde: não pare! Exercício físico em tempos de pandemia, um relato de experiência. Braz J Dev 7(2):12607-12622

61. Xiao $Y$ et al (2021) Impacts of working from home during COVID-19 pandemic on physical and mental well-being of office workstation users. J Occup Environ Med 63(3):181

62. Mello SF, Tomei PA (2021) Desafios da expatriação e o enriquecimento da interface trabalho-família em expatriados, durante a pandemia COVID-19. Revista Gestão Organizacional 14(1):269-293

63. Yildirim TM, Eslen-Ziya H (2021) The differential impact of COVID-19 on the work conditions of women and men academics during the lockdown. Gender Work Org 28:243-249

64. Moretti A et al (2020) Characterization of home working population during COVID-19 emergency: a cross-sectional analysis. Int J Environ Res Public Health 17(17):6284

65. Majumdar P, Biswas A, Sahu S (2020) Pandemia de COVID-19 e bloqueio: causa de perturbações do sono, depressão, dor somática e maior exposição à tela de funcionários de escritório e estudantes da Índia. Chronobiol Int 37(8):1191-1200

66. Tavares FA, da Silva ST, Costa DTS (2020) Isolamento social com crianças: um período de redescoberta da família

67. Pessoa ARR, Moura MMM, de Farias IMS (2021) A composição do tempo social de mulheres professoras durante a pandemia. LICERE-Revista do Programa de Pós-graduação Interdisciplinar em Estudos do Lazer 24(1):161-194

68. Waizenegger L et al (2020) Uma perspectiva econômica de colaboração em equipe e trabalho forçado em casa durante o COVID19. Eur J Inf Syst 29(4):429-442

Publisher's Note Springer Nature remains neutral with regard to jurisdictional claims in published maps and institutional affiliations. 